\title{
BEHAVIORAL ASPECTS IN MISINVOICING RESEARCH AND COMBATTING
}

\section{Anton Zhuchkov ${ }^{1}$}

DOI: https://doi.org/10.30525/978-9934-26-050-6-34

The effectiveness of customs control is a key element of the national economic security and financial interests protection. Modern system of international economic cooperation needs a well-balanced combination of the two main components of the control process: the first one to ensure fraud combating and preventing customs rules violations, and the second one which provides for simplifying and speeding up customs clearance for bona fide traders and legal business. The problem of fraud in international trade as well as tax evasion has been studied by many experts (M. Murray (1991), G. Schulze (1991); B. Javorchik (2008); M. Ferrantino et al. (2008); J. Alm (2012); A. Malezieux (2017); G. Stanescu et al. (2018)), but it still remains relevant and demands further research. To some extent, the results of previous investigations have identified the main purely economic reasons for unfair behavior of economic agents (tax payers) taking the financial decisions in violation of the law terms. These reasons include too strict government

\footnotetext{
${ }^{1}$ University of the State Fiscal Service of Ukraine, Ukraine
} 
regulation, high tax rates, bureaucracy and unreasonable requirements for taxpayers, at the first place. Both individuals and companies certainly take a variety of actions to reduce their tax liabilities obligations. Individuals can evade income taxes by underreporting incomes; by overstating expenses or credits; by failing to file appropriate tax returns; or even by engaging in barter $[1 ; 7 ; 8 ; 16 ; 18]$.

Previous studies focusing on economic agents' behavior and the methods they use to avoid taxation were limited by the framework of the paradigm of classical economic theory by the standpoint of «rationality» of economic agents and their awareness of the results of their decisions. In neoclassical theory the concept of rationality is further associated with profit maximizing. The following assumption is associated with neoclassical concept of rational behavior: when making decisions people are perfectly informed about all choice alternatives, are aware of its limitations and due to these limitations are looking for the best possible choice of means to achieve the goals [15]. Further researches have shown a lot of evidence that in reality it's not the case. Standard economic models cannot properly justify people's behavior in cases when it is inverse to the principle of utility maximization. It is important to analyze decision-making process from different point of view, as economic operators' choice in many cases carries quite noticeable financial risks, not only expected financial benefits. The analysis of tax evading behavior only from the perspective of rationality is incomplete and could neither sufficiently explain the peculiarities of tax evasion, nor propose certain ways to prevent it [13]. Excluding intentional fraud, the said reasons didn't clarify all the variety of undoubtedly non-profitable decisions [2; 3; 10].

In addition to domestic tax evasion research, the problem of fraudulent goods declaring in international trade has been studied in depth in recent years [6; 7; 11; 14]. It's typical not only for developing countries but also for developed countries with stable economies. Tariff evasion and misinvoicing are considered to be a significant damage to national economies and have a consistent and substantial negative impact on the world economy as a whole. Combating these obstacles is a priority in the fight against money laundering by both international organizations and national customs services.

Currently used methods of control and prevention of misinvoicing are evidently not so effective, so the search for more effective mechanisms is actively conducted by experts from different countries [6; 11; 17].

Comprehensive understanding of interactions between economic operators and customs when declaring the goods to the customs clearance can be illustrated as a following decision-making model (see Figure 1): 


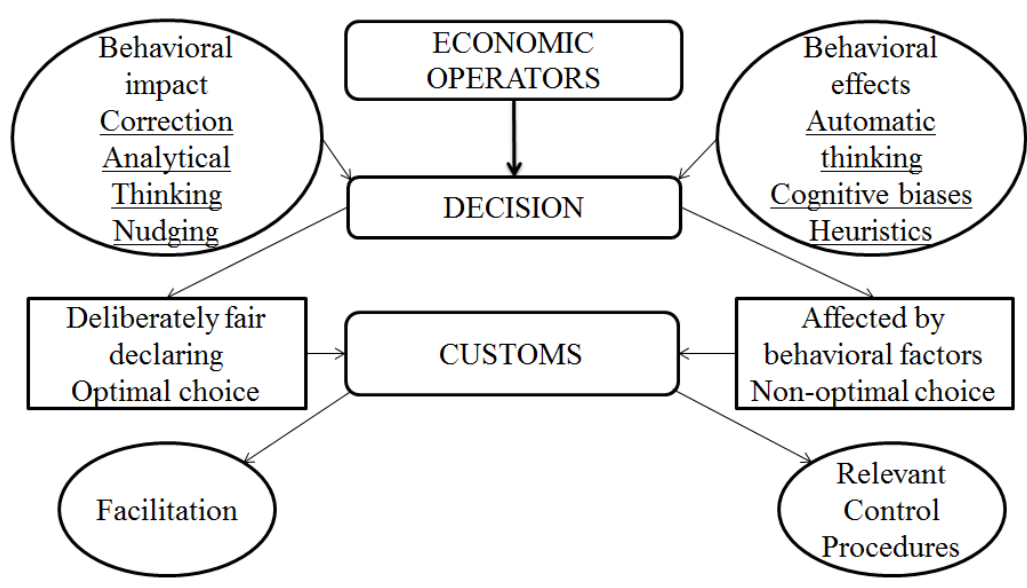

Figure 1. Decision-making model

This model schematically shows the interaction between customs as a controlling body and the economic operator (the importer) as a decisionmaker. The subject of control is the result of this decision (in this case, declaring of certain customs value). The actions of the importer, as financial decisions, have corresponding consequences, both for him and for the state. Depending on the results of the control, the consequences can be positive or negative for the economic operator.

As it was stated above, in classical and neo-classical economic theories, the main argument for decision-making was the desire to achieve optimal results from a financial point of view, to minimize unnecessary costs by increasing profits. In other words, rational choice was understood as an optimal one. In fact, in many cases the decisions of declarants are not really optimal for them (neither financially, nor in the legal framework) and do not lead to profits increase and minimization of expenses, although they may have seemed to be profitable at first glance. The following ones can be distinguished: optimal (rational or deliberately taken which is fair and reveal themselves as the most profitable), non-optimal (inconsiderate or affected by different behavioral and psychological factors), purposely fraudulent (illegal and after all reveal themselves as economically unprofitable).

A common example of non-optimal decisions is an under-invoicing of the imported goods. Under-invoicing entails the appropriate response of customs authorities which carry out the necessary verification measures, apply respective forms of control, which can cause delays in customs clearance, complicate both the customs clearance procedure and leads to negative 
consequences for trader's profile at customs. The stable, reliable and fair relationship between importers and customs is much more profitable providing more transparency and facilitation. But actually the situation is different. Underinvoicing is still often registered in Ukraine as well as in other countries. The situation should be optimized to increase number of fair and deliberately declaring.

Recent findings in behavioral finance allow us to examine this problem from a different point of view and try to identify the points influencing the behavior and choice of economic operators, in particular, in customs clearance process. Despite the fact behavioral economics as a science is a relatively new concept in economic theory, it's methods are widely used by modern researchers to analyze human behavior in the economic and legal system.

A lot interesting attempts of behavior analysis have been undertaken in recent years revealing quite astonishing findings, such as development of the theory of a Dual System of Thinking and the Concept of Nudging. Daniel Kahneman, a Nobel Laureate in Economic Sciences in 2002, is considered by most researchers to be the founder of the behavioral economics. Together with Amos Tversky he proposed a theory of making a choice under uncertainty and risk, a Prospect Theory. Classifying human thinking in two distinct types (System 1 - fast, automatic and effortless and System 2 - slow, analytic and effortful), Kahneman also discovered how human judgments can be predictable and dependable on previous experience and mental shortcuts facilitating decision-making called heuristics [9]. A large amount of experimental evidence in cognitive psychology and neuroscience has shown that people are subjected to many cognitive biases, at least, in automatic decision making, usual activity patterns in a predictable way [5].

After Richard Thaler (Nobel Prize in Economic Sciences in 2017) and Cass Sunstein have formulated the concept of Libertarian Paternalism, the approaches of policymakers in different fields of people's activity have changed significantly. Nudging became a new mechanism supporting well-being and helping people to make optimal choice. The commonly used term «Nudge» was defined by its authors as «any aspect of the choice architecture that alters people's behavior in a predictable way without forbidding any options or significantly changing their economic incentives». Elements of nudging are implemented into government operations in some countries being early adopters in the field: Australia, Canada, Denmark, France, Germany, Netherlands, Peru, Singapore, the U.S., and the UK. In the last few years an increasing number of public bodies became interested in leveraging behavioral insights for improving policies and services. Behavioural Insights have progressively been recognised as a valuable input to policy-making by major international organisations, such 
as the European Commission, the Organisation for Economic Co-operation and Development and the World Bank [4].

By changing the «choice architecture» within which individuals make their automatic decisions, policy makers can «nudge» individuals away from their fast and in ways that encourage them to make better informed decisions without mandating that individuals behave in proscribed ways [12]. Further investigations are necessary to identify factors have the most significant impact on decision-making process by customs clearance and elaborate a relevant mechanism of nudging in this field.

\section{References:}

1. Alm, J. (2012). Measuring, explaining, and controlling tax evasion: lessons from theory, experiments, and field studies International Tax and Public Finance, ISSN 0927-5940, Volume 19, Number 1, doi: 10.1007/s10797-011-9171-2

2. Camerer, C. (1998). Prospect Theory In The Wild: Evidence From The Field. Advances in Behavioral Economics.

3. Camerer, C., Loewenstein, G. (2004). Behavioral Economics: Past, Present, Future. Advances in Behavioral Economics. URL: https://www.researchgate.net/ publication/228359684_Behavioral_Economics_Past_Present_Future

4. Chetty, Raj (2015). Behavioral Economics and Public Policy: A Pragmatic Perspective †. American Economic Review, 105, 1-33. doi: 10.1257/aer.p20151108

5. Fenton-O'Creevy, M., Soane, E., Nicholson, N. and Willman, P. (2011). Thinking, feeling and deciding: The influence of emotions on the decision making and performance of traders. J. Organiz. Behav., 32: 1044-1061. doi: 10.1002/job.720

6. Ferrantino, M. J., Liu, X., Wang, Z. (2008). Avoidance Behaviors of Exporters and Importers: Evidence from the U.S.-China Trade Data Discrepancy. U.S. International Trade Commission Economics Working Paper No. 2008-09-B. doi: 10.2139/ssrn.1266159

7. Forstater, M. (2018). Illicit Financial Flows, Trade Misinvoicing, and Multinational Tax Avoidance: The Same or Different? CGD Policy Paper. Washington, DC: Center for Global Development. URL: https://www.cgdev.org/ publication/illicit-financial-flows-trade-misinvoicing-and-multinational-taxavoidance

8. Javorcik, B.S., Narciso, G. (2007). Differentiated Products and Evasion of Import Tariffs. World Bank Policy Research Working Paper 4123. URL: http://documents1.worldbank.org/curated/en/166091468037502696/pdf/wps4123.Pdf

9. Kahneman D., Frederick S., (2005) A Model of Heuristic Judgment. URL: https://www.psychologytoday.com/sites/default/files/model_of_heuristic_judgment.pdf

10. Kannengiesser, U., Gero, J. (2019). Empirical Evidence for Kahneman's System 1 and System 2 Thinking in Design. URL: https://www.researchgate.net/ publication/330764830_Empirical_Evidence_for_Kahneman's_System_1_and_System_ 2_Thinking_in_Design

11. Kuntal K. Das, Laura Meriluoto \& Amy Rice (2020) Export tax and importtariff avoidance: evidence from the trade data discrepancy in the China - New Zealand 
trade, New Zealand Economic Papers, 54: 2, 161-189. doi: 10.1080/00779954.2019. 1624598

12. Lourenço J. S., Emanuele Ciriolo, Sara Rafael Almeida, and Xavier Troussard; Behavioural insights applied to policy: European Report 2016. EUR 27726 EN. doi:10.2760/903938. URL: https://ec.europa.eu/jrc/en/publication/eur-scientific-andtechnical-research-reports/behavioural-insights-applied-policy-european-report-2016

13. Malezieux, A. (2017). Essays in Economic Psychology of Tax Evasion Behavior. Economics and Finance. Doctoral thesis for the degree of Doctor of Philosophy in economics, Université de Lorraine, English. NNT: 2017LORR0062f

14. Schulze, G. (1991). Stating import prices wrongly: Possibilities of tax and tariff evasion, Diskussionsbeiträge - Serie II, No. 138, Universität Konstanz, Sonderforschungsbereich 178 - Internationalisierung der Wirtschaft, Konstanz.

15. Soukup, A., Maitah, M., Svoboda, R. (2014). The Concept of Rationality in Neoclassical and Behavioural Economic Theory. Modern Applied Science. 9. doi: 10.5539/mas.v9 n3p1

16. Stanescu, G., Comandaru A., Paduraru (Horaicu) A. (2018). The phenomenon of tax evasion and the need to combat tax evasion. 3. 124. URL: https://www.researchgate.net/publication/328354434_THE_PHENOMENON_OF_ TAX_EVASION_AND_THE_NEED_TO_COMBAT_TAX_EVASION

17. Stankevicius, E., Leonas, L. (2015). Hybrid approach model for prevention of tax evasion and fraud, 20th International Scientific Conference Economics and Management, Procedia - Social and Behavioral Sciences 213 (2015), pp. 383-389.

18. Yalama, G. Oz., Gumus, E. (2013). Determinants of Tax Evasion Behavior: Empirical Evidence from Survey Data. International Business and Management, vol. 6, no. 2, pp. 15-23. doi: 10.3968/j.ibm.1923842820130602.1085 